PONTIFícIa UNIVERSIDADE CATÓlicA do RIO dE JANEIRO

\title{
O Impacto Causado pelo Insider Trading: Análise do Caso Sadia-Perdigão
}

Caio Moneró Ganem

Trabalho de Conclusão de Curso

Centro de ciências socials - CCS DEPARTAMENTO DE ADMINISTRAÇÃO Graduação em Administração de Empresas 


\title{
Caio Moneró Ganem
}

\section{O Impacto Causado pelo Insider Trading: Análise do Caso Sadia-Perdigão}

\author{
Trabalho de Conclusão de Curso
}

Trabalho de Conclusão de Curso, apresentado ao programa de graduação em Administração da PUC-Rio como requisito parcial para a obtenção do título de graduação em Administração.

Orientador: André Cabús Klötzle 


\section{Resumo}

Moneró, Caio. O Impacto Causado pelo Insider Trading: Análise do Caso Sadia-Perdigão. Rio de Janeiro, 2021. 31p. Trabalho de Conclusão de Curso - Departamento de Administração. Pontifícia Universidade Católica do Rio de Janeiro.

O chamado insider trading está relacionado à utilização de informações privilegiadas aspirando vantagem própria, por intermédio da movimentação de valores mobiliários. O presente trabalho objetiva apresentar o caso de insider trading decorrente da Oferta Pública de Aquisição feita pela Sadia à Perdigão e o impacto causado pela prática ilícita no resultado financeiro e na cotação das ações das empresas envolvidas. A partir da divulgação dos resultados financeiros pelas companhias e do histórico de cotações de suas ações, foi realizada uma análise dos dados coletados à época do episódio. Ainda que seja identificado um impacto considerável no período do incidente, este não se demonstra definitivo.

\section{Palavras-chave:}

Insider trading; Sadia; Perdigão

\section{Abstract}

Moneró, Caio. The Impact Caused by Insider Trading: Analysis of the Sadia-Perdigão Case. Rio de Janeiro, 2021. 31p. Trabalho de Conclusão de Curso - Departamento de Administração. Pontifícia Universidade Católica do Rio de Janeiro.

The insider trading is related to the use of privileged information by a socalled insider, seeking his own benefit, through the transaction of securities. The present study aims to introduce the insider trading case resulting from the tender offer made by Sadia aiming the stocks of its competitor Perdigão and the impact caused by the illegal practice on the financial result of the companies and their stock prices. Based on the disclosure of their financial results and their share prices at the time of the incident, it was performed an analysis of the data collected at the time of the episode. Although a considerable impact is identified, it does not prove to be definitive.

\section{Keywords:}

Insider trading; Sadia; Perdigão 


\section{Sumário}

1 O tema e o problema de estudo 1

1.1. Introdução ao tema e ao problema do estudo 1

1.2. Objetivo do estudo 3

1.3. Objetivos intermediários do estudo 3

1.4. Delimitação do estudo 3

1.5. Justificativa e relevância do estudo 3

2 Referencial Teórico 5

2.1. Definição de Insider Trading 5

2.2. Indicadores Financeiros $\quad 7$

2.2.1. Receita Bruta 7

2.2.2. Receita Líquida 7

2.2.3. Lucro Bruto $\quad 7$

2.2.4. Margem Bruta $\quad 7$

2.2.5. Lucro Líquido

2.2.6. Margem Líquida 8

3 Apresentação e Análise dos Resultados 9

3.1. O Caso Sadia-Perdigão 9

3.2. Resultados Financeiros 11

3.2.1. Sadia 11

3.2.2. Perdigão 13

3.2.3. Análise Comparativa Sadia-Perdigão 14

3.2.3.1. Receita Bruta 14

$\begin{array}{ll}\text { 3.2.3.2. Receita Líquida } & 15\end{array}$

3.2.3.3. Lucro Bruto 16

$\begin{array}{ll}\text { 3.2.3.4. Margem Bruta } & 17\end{array}$

3.2.3.5. Lucro Líquido 18

$\begin{array}{ll}\text { 3.2.3.6. Margem Líquida } & 19\end{array}$

3.3. Impacto na Cotação das Ações 20 
3.3.1. Perdigão 20

$\begin{array}{ll}\text { 3.3.2. Sadia } & 24\end{array}$

4 Conclusão $\quad 26$

5 Referências Bibliográficas 28

\section{Lista de Figuras}

Figura 1: Receita Bruta Sadia-Perdigão (2004-2008) ................................... 15

Figura 2: Receita Líquida Sadia-Perdigão (2004-2008) .................................. 16

Figura 3: Lucro Bruto Sadia-Perdigão (2004-2008) ...................................... 17

Figura 4: Margem Bruta Sadia-Perdigão (2004-2008) ................................... 18

Figura 5: Lucro Líquido Sadia-Perdigão (2004-2008) .................................... 19

Figura 6: Margem Líquida Sadia-Perdigão (2004-2008) ................................ 20

Figura 7: Cotação NYSE: PDA (junho/2006 a agosto/2006) ........................... 21

Figura 8: Cotação PRGA3 (junho/2006 a agosto/2006)................................ 22

Figura 9: Cotação NYSE: PDA (fevereiro/2007 a abril/2007) .......................... 23

Figura 10: Cotação PRGA3 (fevereiro/2007 a abril/2007)................................ 24

Figura 11: Cotação SDIA4 (junho/2006 a agosto/2006) ................................. 25

Figura 12: Cotação SDIA4 (fevereiro/2007 a abril/2007) ................................. 25

\section{Lista de Tabelas}

Tabela 1: Resultado Financeiro Sadia (2004-2008).................................... 12

Tabela 2: Análise Horizontal Sadia (2004-2008) ........................................... 12

Tabela 3: Resultado Financeiro Perdigão (2004-2008) …............................... 13

Tabela 4: Análise Horizontal Perdigão (2004-2008) ....................................... 14

Tabela 5: Receita Bruta Sadia-Perdigão (2004-2008) ................................... 14 
Tabela 6: Receita Líquida Sadia-Perdigão (2004-2008) .................................. 15

Tabela 7: Lucro Bruto Sadia-Perdigão (2004-2008) ...................................... 16

Tabela 8: Margem Bruta Sadia-Perdigão (2004-2008) ................................... 17

Tabela 9: Lucro Líquido Sadia-Perdigão (2004-2008) ................................... 18

Tabela 10: Margem Líquida Sadia- Perdigão (2004-2008) ............................. 19 


\section{0 tema e o problema de estudo}

\subsection{Introdução ao tema e ao problema do estudo}

O insider trading é um dos principais crimes contra o mercado de capitais e consiste, consoante o Artigo 27-D da Lei no 6.385/76, em:

\footnotetext{
Utilizar informação relevante de que tenha conhecimento, ainda não divulgada ao mercado, que seja capaz de propiciar, para si ou para outrem, vantagem indevida, mediante negociação, em nome próprio ou de terceiros, de valores mobiliários.

Pena - reclusão, de 1 (um) a 5 (cinco) anos, e multa de até 3 (três) vezes o montante da vantagem ilícita obtida em decorrência do crime (BRASIL, 1976).
}

A infração, em outras palavras, se fundamenta no uso das chamadas informações privilegiadas, obtidas antecipadamente a partir de um fato relevante ainda não divulgado ao mercado. Tais informações, por sua vez, são conceituadas legalmente como acontecimentos que têm poder de influência momentânea sobre a decisão dos investidores acerca da venda ou compra de determinado valor mobiliário.

São chamados insiders os indivíduos que realizam a atividade. Conforme determinado pela Comissão de Valores Mobiliários (CVM), podem ser tidos como insiders os indivíduos, de alguma forma, capazes de obter as informações não disponíveis aos demais investidores, sendo estes: (i) acionistas controladores; (ii) conselheiros; (iii) diretores; (iv) membros do Conselho Fiscal; (v) membros de quaisquer órgãos criados pelo estatuto da companhia, com funções técnicas ou destinadas a aconselhar os administradores; (vi) subordinados das pessoas acima referidas; e (vii) terceiros de confiança dessas pessoas. Assim sendo, pode-se constatar que não apenas funcionários ou profissionais que possuam vínculos diretos com as companhias são responsáveis pela prática da atividade ilegal.

Dessarte, Custódio (2018) reconhece a divisão do insider trading em duas distintas categorias, o primário e o secundário. O chamado insider trading primário ocorre quando o agente do crime possui acesso natural e legal à informação privilegiada, isto é, quando a violação é cometida por um acionista 
majoritário, um administrador da companhia ou, em última instância, um prestador de serviço, como é o exemplo de advogados ou contadores terceirizados. Já o insider trading secundário é caracterizado pela atuação ilícita realizada por um indivíduo que tem acesso à informação privilegiada através de um agente primário. Contudo, nem sempre esta transmissão de informações é efetuada de maneira proposital, podendo também ser adquirida por meio de um vazamento de informações, a título de exemplo.

Os Estados Unidos são pioneiros no estabelecimento de leis no que concerne ao insider trading e na condenação de insiders. De acordo com a revista Forbes (2019), a primeira evidência de uma infração ocorrida no mercado americano é datada de 1789, cometida por William Duer, à época assistente do Secretário do Tesouro Nacional, que utilizou as informações confidenciais às quais tinha acesso para especular ações e títulos. A primeira lei proibitiva em relação à atividade, por sua vez, foi implementada somente no ano de 1934 , devido ao grande número de casos de insider trading ocorridos em decorrência da Crise de 1929. Um dos infratores mais conhecidos foi Albert H. Wiggin, diretor do Chase National Bank, que "shorteou" (vendeu a descoberto) mais de 40.000 ações do banco e obteve, com isso, um lucro superior a US\$ 4 milhões.

No Brasil, alguns casos se tornaram muito conhecidos, sobretudo mais recentemente, por conta da maior visibilidade do mercado financeiro entre os cidadãos. O primeiro caso se deu em 2006, quando, anteriormente à divulgação ao mercado de que a Sadia adquiriria mais de 50\% da participação acionária da Perdigão, o ex-diretor de Finanças e Relações com Investidores e um membro do Conselho de Administração da Sadia compraram um altíssimo volume de ADRs da Perdigão, negociados na Bolsa de Nova York. Além desse, outro exemplo é o caso Joesley Batista, no qual o Banco Original, parte do Grupo J\&F, do qual Joesley é proprietário, realizou operações com derivativos de taxa de câmbio precedentemente ao acordo de delação premiada realizado entre ele e o Ministério Público (MP). Ainda, mais recente, podemos lembrar do caso investigado pela CVM que diz respeito à suspeita de insider trading em operações com opções da Petrobras, realizadas com base em informações privilegiadas sobre mudança na presidência da organização.

Não obstante todos os casos aqui apresentados serem relevantes 0 presente trabalho focará na Sadia-Perdigão, cuja fusão foi anunciada em 2009 e concluída em 12/06/2013, após a aprovação pelo Conselho Administrativo de Defesa Econômica (CADE), que resultou na criação da Brasil Foods (BRF). 


\subsection{Objetivo do estudo}

O presente trabalho tem como objetivo avaliar o impacto causado pelo insider trading na empresa envolvida, qual seja, Sadia-Perdigão.

\subsection{Objetivos intermediários do estudo}

Este ensaio irá, a fim de alcançar o objetivo final referido, atingir os seguintes objetivos intermediários: i) apresentar um caso de insider trading ocorrido no cenário brasileiro, sendo este o caso Sadia-Perdigão; ii) analisar os resultados financeiros e o comportamento das ações prévia e posteriormente aos acontecimentos; e iii) observar, a partir de ambas as óticas, o impacto causado pelo episódio.

\subsection{Delimitação do estudo}

A delimitação do estudo será o caso selecionado e mencionado no tópico anterior para análise. Embora haja outros casos ocorridos no Brasil e inúmeros nos mercados europeus e dos Estados Unidos, este trabalho se restringirá à inspeção deste específico acontecimento.

\subsection{Justificativa e relevância do estudo}

O presente trabalho se mostra relevante em diversas esferas. Primeiramente, é importante para os órgãos reguladores, uma vez que, como definido pela Comissão de Valores Mobiliários (CVM):

O insider trading fere gravemente o princípio central da regulação do mercado de capitais, qual seja, o princípio do full and fair disclosure e, portanto, abala a credibilidade, a estabilidade e a eficiência do mercado de capitais (CVM).

Por sua vez, para as companhias de capital aberto, isto é, que possuem suas ações listadas na Bolsa de Valores, o ensaio é pertinente por destacar a importância da devida prevenção e condenação desta prática dentro das organizações. Ainda, é importante ressaltar os deveres que estas empresas possuem, sobretudo os que dizem respeito à necessidade de divulgação ao mercado e comunicação à CVM em caso de fato relevante. De acordo com a 
Comissão, este comunicado deve ser realizado antes do começo ou após o término das negociações nas Bolsas, à exceção de casos nos quais seja estritamente necessária a comunicação durante o pregão, o que deve determinar a interrupção momentânea da negociação do determinado ativo.

Por fim, para os investidores, o presente trabalho também se apresenta relevante, devido à análise do comportamento a longo prazo das ações da empresa envolvida no evento. 


\section{Referencial Teórico}

\subsection{Definição de Insider Trading}

Rodrigues (apud BOLSON; KRIEGER, 2018, p. 273) define o insider trading como a fusão de duas palavras: insider, que se refere a um indivíduo que, mediante sua profissão ou seu status, obtém informações até então não divulgadas ao público a respeito de uma sociedade; e trading, derivado do verbo inglês "to trade", referente à negociação e transação de valores.

De acordo com o advogado e professor Nelson Eizirik, como citado por Bolson e Krieger (2018, p. 272), o insider trading corresponde ao uso de informações relevantes acerca de valores mobiliários, por indivíduos que, através de sua atividade profissional, encontram-se cientes das negociações realizadas pela empresa emissora, a fim de operar os ativos anteriormente à comunicação de tais informações ao mercado, isto é, antes que estes fatos se tornem de conhecimento público. $O$ autor afirma que o insider atua na compra ou na venda dos títulos a um preço que ainda não representa o impacto de informações que sejam de sua ciência exclusiva.

Frente a isso, é importante delimitar o conceito de informação relevante. Esta é definida pelo Art. $2^{\circ}$ da Instrução CVM no 358 como:

\footnotetext{
Qualquer decisão de acionista controlador, deliberação da assembléia geral ou dos órgãos de administração da companhia aberta, (...) que possa influir de modo ponderável: i) na cotação dos valores mobiliários de emissão da companhia aberta ou a eles referenciados; ii) na decisão dos investidores de comprar, vender ou manter aqueles valores mobiliários; e iii) na decisão dos investidores de exercer quaisquer direitos inerentes à condição de titular de valores mobiliários emitidos pela companhia ou a eles referenciados.
}

Por sua vez, Eizirik caracteriza as informações privilegiadas de modo que estas: i) devem possuir um caráter razoavelmente concreto, isto é, fazer alusão a uma situação verídica e não a simples boatos; ii) ainda não tenham sido comunicadas ao público; iii) sejam consideradas price sensitives, ou seja, 
possam afetar a cotação dos ativos, uma vez reveladas; e iv) digam respeito a valores mobiliários ou aos seus respectivos emissores (BOLSON; KRIEGER, 2018).

A advogada Norma Jonssen Parente (1978), em nome da CVM, classifica o insider trading como toda transação que envolva valores mobiliários emitidos por uma companhia, efetuada por um insider visando interesse e vantagem própria. Ainda explicita que uma operação executada por um insider se configura ilícita, exclusivamente, caso apresente características estabelecidas por intermédio da lei. A referida caracterização da atividade como ilegítima encontrase exposta na Lei ํㅜ 6.404/76, Lei ํㅜ 6.385/76 e na ICVM no 358/2002.

A Comissão de Valores Mobiliários determina a obrigatoriedade por parte das companhias de comunicação imediata ao mercado perante qualquer fato relevante que esteja associado aos seus negócios. O dever de informar às demais instituições e aos investidores está diretamente relacionado ao princípio fundamental do mercado de capitais, o chamado princípio do full and fair disclosure. Este fundamenta-se na suposição de que, uma vez fornecidas as informações relevantes no tocante à companhia e seus valores mobiliários, os investidores são capazes de aferir o devido valor da empresa e de seus ativos, precificando-os de modo justo (MAHONEY, 2001).

A Securities and Exchange Comission (SEC), agência federal responsável pela regulamentação e pelo controle do mercado financeiro norte-americano, equivalente à CVM no Brasil, define a infração como a negociação de um título no instante em que o agente possui informações não públicas acerca do ativo. Atentam ainda para o fato de que a violação pode se originar a partir das denominadas "tips", dicas a respeito de tais informações privilegiadas (SEC, 2013, tradução própria).

À vista da qualificação do insider trading na legislação brasileira, vale destacar que Graziani (2018) aborda a ineficiência de criminalização da prática, assim como questiona sua condenação nas esferas cível e administrativa. $O$ autor considera a alternativa de reconhecer o insider trading como um acontecimento natural ao mercado e alega que a sua classificação como infração não o impossibilita e, tampouco, reduz sua prática de modo significativo. Graziani (2018) argumenta que o Direito Penal está relacionado ao direito mais sensível ao qual se pode privar o indivíduo: a liberdade. 


\subsection{Indicadores Financeiros}

Objetivando analisar o impacto causado pelo episódio de insider trading no resultado financeiros das empresas Sadia e Perdigão, serão ponderados diferentes indicadores financeiros. A seguir, nas seções posteriores, tais indicadores serão apresentados e explicitados.

\subsubsection{Receita Bruta}

A receita bruta, de acordo com Reis (2018), é o indicador que representa o faturamento da empresa, isto é, exprime a totalidade de vendas de produtos e prestações de serviços de uma companhia.

\subsubsection{Receita Líquida}

A receita líquida, por sua vez, está relacionada ao resultado auferido pela empresa por meio de suas operações (venda de produtos e/ou prestação de serviços), depois da dedução de devoluções, descontos e impostos sobre as vendas (REIS, 2018).

\subsubsection{Lucro Bruto}

Segundo Reis (2018), o lucro bruto pode também ser denominado lucro operacional bruto ou lucro das vendas, e retrata a diferença obtida pela instituição e seus custos variáveis, os quais referem-se aos custos que estão associados diretamente à produção.

\subsubsection{Margem Bruta}

Consoante Reis (2019), a margem bruta é calculada a partir da razão entre o lucro bruto e a receita líquida.

\subsubsection{Lucro Líquido}

No que concerne ao lucro líquido, este indicador diz respeito à diferença entre a receita total auferida pela empresa e seus custos totais. Assim, infere-se que este pode ser calculado a partir do lucro bruto, abatendo, além dos custos variáveis já deduzidos, os custos fixos da empresa, os quais são independentes em relação à produção (REIS, 2018). 


\subsubsection{Margem Líquida}

Por fim, a margem líquida indica a proporção do lucro líquido com relação à receita líquida e é calculada a partir da divisão dos indicadores, respectivamente (REIS, 2017). 


\section{Apresentação e Análise dos Resultados}

O presente capítulo pretende, além de apresentar o caso selecionado para análise, expor os dados coletados, os quais, como mencionados previamente, referem-se aos resultados financeiros das companhias envolvidas, bem como 0 comportamento de suas ações negociadas na B3, única Bolsa de Valores do Brasil.

\subsection{O Caso Sadia-Perdigão}

O episódio de tentativa de compra da Perdigão pela Sadia definido para análise e ocorrido em 2006, refere-se à primeira e, até o momento, única condenação penal por insider trading no Brasil. O caso é concernente à Oferta Pública de Aquisição (OPA), por parte da Sadia, que objetivava adquirir o controle acionário de sua concorrente Perdigão. Frente à estratégia definida pela companhia, dois executivos da Sadia, à época, o diretor financeiro e de Relações com Investidores, Luiz Gonzaga Murat Júnior, e o integrante do Conselho de Administração, Romano Ancelmo Fontana Filho, sobrinho de Attilio Fontana, fundador do Grupo Sadia, utilizaram a informação privilegiada sobre a oferta com o intuito de obter vantagem no mercado acionário. As operações efetuadas pelos executivos envolviam ADRs (American Depositary Receipts) da Perdigão, negociados na Bolsa de Valores de Nova York, e foram realizadas entre abril e julho de 2006.

A primeira transação foi executada em 7 de abril de 2006 por Luiz Murat, no dia em que se iniciaram as tratativas acerca da OPA, em uma reunião na qual estavam presentes ele próprio, o presidente do Conselho de Administração da Sadia, Walter Fontana e uma equipe do banco holandês ABN. O Diretor de Relações com Investidores (DRI) da Sadia adquiriu 15.300 ADRs da Perdigão no mercado acionário norte-americano pelo valor apurado de US $\$ 352.907,00$. Nos meses subsequentes, após as negociações já se apresentarem em etapa mais avançada, Luiz Murat adquiriu, em 29 de junho de 2006, um novo lote de 30.600 ADRs da concorrente, em uma operação avaliada em US\$586.801,00. Às vésperas do comunicado oficial da Sadia ao mercado, Romano Fontana Filho, 
por sua vez, comprou 18.000 ADRs da Perdigão, entre os dias 5 e 12 de julho de 2006, negociação precificada em US\$344.100,00.

A Oferta Pública de Aquisição da Sadia se tornou de conhecimento público em 16 de julho de 2006. Não obstante o interesse por parte da Sadia na concretização da oferta, os acionistas do grupo Perdigão a recusaram e, no dia 21 de julho, a Sadia divulgou a revogação efetiva da OPA. No mesmo dia da referida comunicação ao mercado da negativa à proposta, Luiz Murat e Romano Fontana efetuaram a venda dos ADRs.

Os executivos foram punidos nos Estados Unidos pela Securities and Exchange Comission (SEC), órgão regulador do mercado acionário norteamericano, e no Brasil pela Comissão de Valores Mobiliários (CVM). No ano posterior à sequência de acontecimentos, em 2007, a SEC chegou a um acordo com os acusados, no qual ambos deveriam ficar afastados por, no mínimo, cinco anos de cargos administrativos em quaisquer empresas de capital aberto, cujos títulos fossem negociados no mercado estadunidense. Outrossim, Romano consentiu o pagamento de US\$ 316.714,00 à SEC e Murat foi multado em US\$ $364.000,00$.

Ainda que as operações tenham sido realizadas na Bolsa de Nova York, a Comissão de Valores Mobiliários brasileira, no que lhe concerne, julgou ser competente para condenar os envolvidos, frente ao estabelecido no $\S 6^{\circ}$ do art. 9 da Lei 6.385/7675:

\begin{abstract}
A Comissão será competente para apurar e punir condutas fraudulentas no mercado de valores mobiliários sempre que: i) seus efeitos ocasionem danos a pessoas residentes no território nacional, independentemente do local em que tenham ocorrido; e ii) os atos ou omissões relevantes tenham sido praticados em território nacional.
\end{abstract}

No início de 2008, a CVM, assim como a SEC, sentenciou Romano Ancelmo Fontana Filho e Luiz Murat Junior a permaneceram afastados, por um hiato de cinco anos, de cargos administrativos de empresas de capital aberto no Brasil. Em 2011, no entanto, a CVM, juntamente com o Ministério Público Federal (MPF), decretou a primeira e, até o momento da elaboração deste trabalho, única condenação penal por insider trading no Brasil. As penas definidas foram de um ano e nove meses de prisão para o ex-diretor de finanças e RI, e de um ano e cinco meses para o ex-integrante do Conselho de 
Administração, ambas em regime aberto, sendo possível sua substituição pela prestação de serviços comunitários, além das determinadas multas nos valores de $R \$ 349,7$ mil e $R \$ 374,9$ mil para Luiz Murat e Romano Fontana Filho, respectivamente. Ademais, em 2013, o Tribunal Regional Federal da $3^{\underline{a}}$ Região (TRF-3), ao alegar dano moral coletivo, estipulou novas multas de $R \$ 303$ mil para Romano Fontana e de $\mathrm{R} \$ 254$ mil para Luiz Murat, perpetuando as multas designadas na condenação prévia.

\subsection{Resultados Financeiros}

Nos capítulos pospositivos, serão expostos os resultados financeiros divulgados pela companhia à época das condenações concernentes ao caso de insider trading ocorrido em 2006. Para fundamentar a análise, os capítulos a seguir discorrerão a respeito dos resultados financeiros de Sadia e Perdigão entre os anos de 2004 e 2008, promovendo uma comparação entre os dados das empresas.

\subsubsection{Sadia}

A presente seção objetiva apresentar o resultado financeiro auferido pela Sadia S.A. entre os anos de 2004 e 2008. Ainda, será elaborada uma análise horizontal dos dados encontrados, buscando verificar a variação percentual entre os valores anuais obtidos.

Vale ressaltar que, em 2009, a Sadia passou por um processo de incorporação pela Perdigão, o qual foi estimulado pelo seu enorme prejuízo líquido, decorrente do endividamento bilionário da empresa no ano anterior (vide Tabela 1), devido à realização de operações financeiras de hedge (proteção) contra a queda do dólar. As operações efetuadas com derivativos cambiais visavam proteger a receita proveniente das exportações, no caso de valorização da moeda nacional e consequente desvalorização da moeda estrangeira.

Todavia, muitas dessas operações foram efetuadas em valores superiores ao necessário para efetiva proteção, resultando em forte prejuízo quando houve reversão do movimento de valorização do Real durante a crise do mercado de hipotecas subprime norte-americano, em 2008. 
Tabela 1: Resultado Financeiro Sadia (2004-2008)

\begin{tabular}{|l|c|c|c|c|c|}
\hline \multicolumn{7}{|c|}{ Sadia (R\$ milhões) } \\
\hline Receita Bruta & $\mathbf{2 0 0 4}$ & $\mathbf{2 0 0 5}$ & $\mathbf{2 0 0 6}$ & $\mathbf{2 0 0 7}$ & $\mathbf{2 0 0 8}$ \\
\hline Receita Líquida & 7.317 & 8.328 & 7.940 & 9.844 & 12.192 \\
\hline Lucro Bruto & 6.379 & 7.318 & 6.877 & 8.632 & 10.729 \\
\hline Margem Bruta (\%) & 1.917 & 2.007 & 1.691 & 2.311 & 2.619 \\
\hline Lucro Líquido & 30,1 & 27,4 & 24,6 & 26,8 & 24,4 \\
\hline Margem Líquida (\%) & 439 & 657 & 377 & 689 & -2.485 \\
\hline
\end{tabular}

Fonte: Elaborada pelo autor (2021)

A partir da Tabela 2, é possível realizar um diagnóstico da evolução anual dos resultados financeiros da Sadia. Consoante aos dados apresentados, é válido constatar que no ano de 2006, no qual ocorreu o fato, todos os parâmetros apresentaram redução, com destaque para o lucro líquido, o qual expressou contração superior a 40\%. No período contábil subsecutivo, em 2007, os indicadores se recuperaram, evidenciando um crescimento médio considerável do lucro líquido, excedendo os $80 \%$. No ano seguinte, em 2008 , contudo, o endividamento referente à alavancagem financeira através das operações com derivativos impactou substancialmente o resultado da empresa. Ainda que as receitas bruta e líquida exprimam crescimento em torno de $25 \%$, a companhia incorreu em um prejuízo líquido de $R \$ 2,5$ bilhões, uma retração de mais de $460 \%$ (vide Tabela 2 ).

Tabela 2: Análise Horizontal Sadia (2004-2008)

\begin{tabular}{|l|c|c|c|c|c|c|c|c|c|}
\hline \multicolumn{10}{|c|}{ Sadia (R\$ milhões) } \\
\hline & $\mathbf{2 0 0 4}$ & $\mathbf{\Delta} \%$ & $\mathbf{2 0 0 5}$ & $\mathbf{\Delta} \%$ & $\mathbf{2 0 0 6}$ & $\boldsymbol{\Delta} \%$ & $\mathbf{2 0 0 7}$ & $\boldsymbol{\Delta} \%$ & $\mathbf{2 0 0 8}$ \\
\hline Receita Bruta & 7.317 & 13,82 & 8.328 & $-4,66$ & 7.940 & 23,98 & 9.844 & 23,85 & 12.192 \\
\hline Receita Líquida & 6.379 & 14,72 & 7.318 & $-6,03$ & 6.877 & 25,52 & 8.632 & 24,29 & 10.729 \\
\hline Lucro Bruto & 1.917 & 4,69 & 2.007 & $-15,74$ & 1.691 & 36,66 & 2.311 & 13,33 & 2.619 \\
\hline Margem Bruta (\%) & 30,1 & $-8,74$ & 27,4 & $-10,34$ & 24,6 & 8,88 & 26,8 & $-8,82$ & 24,4 \\
\hline Lucro Líquido & 439 & 49,66 & 657 & $-42,62$ & 377 & 82,76 & 689 & $-460,67$ & -2.485 \\
\hline Margem Líquida (\%) & 6,9 & 30,46 & 9,0 & $-38,94$ & 5,5 & 45,60 & 8,0 & $-390,17$ & $-23,2$ \\
\hline
\end{tabular}

Fonte: Elaborada pelo autor (2021) 


\subsubsection{Perdigão}

Adiante, será exposto o resultado financeiro da Perdigão e estruturada uma análise horizontal do material coletado. A Perdigão, no ano de 2009, aproveitou a dívida bilionária da Sadia para incorporar a concorrente e dar origem à Brasil Foods (BRF), uma gigante do setor alimentício. A partir da união das duas companhias, a nova BRF assegurou sua colocação entre os dez maiores grupos alimentícios das Américas. A referida lista é composta, hegemonicamente, pelas enormes norte-americanas do segmento, onde aparece apenas mais uma brasileira, a JBS Friboi. No setor de abate, devido à forte atuação da BRF no ramo de frangos (no qual assumiu posteriormente a liderança mundial), a companhia alcançou o terceiro lugar geral.

Tabela 3: Resultado Financeiro Perdigão (2004-2008)

\begin{tabular}{|l|c|c|c|c|c|}
\hline \multicolumn{7}{|c|}{ Perdigão (R\$ milhões) } \\
\hline & $\mathbf{2 0 0 4}$ & $\mathbf{2 0 0 5}$ & $\mathbf{2 0 0 6}$ & $\mathbf{2 0 0 7}$ & $\mathbf{2 0 0 8}$ \\
\hline Receita Bruta & 5.567 & 5.873 & 6.106 & 7.789 & 13.161 \\
\hline Receita Líquida & 4.883 & 5.145 & 5.210 & 6.633 & 11.393 \\
\hline Lucro Bruto & 1.351 & 1.459 & 1.344 & 1.873 & 2.759 \\
\hline Margem Bruta (\%) & 27,7 & 28,4 & 25,8 & 28,2 & 24,2 \\
\hline Lucro Líquido & 296 & 361 & 117 & 321 & 155 \\
\hline Margem Líquida (\%) & 6,1 & 7,0 & 2,2 & 4,8 & 1,4 \\
\hline
\end{tabular}

Fonte: Elaborada pelo autor (2021)

Com base na análise horizontal do resultado financeiro auferido pela Perdigão entre 2004 e 2008 (vide Tabela 4), percebe-se que no ano do acontecimento de insider trading envolvendo a companhia (2006), o lucro líquido e, por conseguinte, a margem líquida evidenciaram considerável queda. Tal como observado na análise referente à Sadia, a Perdigão também apresentou em 2008, apesar do aumento de aproximadamente $70 \%$ nas receitas bruta e líquida, uma redução expressiva no lucro líquido. A aludida queda se deveu, sobretudo, ao aumento do endividamento em moeda nacional e estrangeira frente à crise econômica de 2008. 
Tabela 4: Análise Horizontal Perdigão (2004-2008)

\begin{tabular}{|l|c|c|c|c|c|c|c|c|c|}
\hline \multicolumn{10}{|c|}{ Perdigão (R\$ milhões) } \\
\hline & $\mathbf{2 0 0 4}$ & $\mathbf{\Delta} \%$ & $\mathbf{2 0 0 5}$ & $\boldsymbol{\Delta} \%$ & $\mathbf{2 0 0 6}$ & $\mathbf{\Delta} \%$ & $\mathbf{2 0 0 7}$ & $\mathbf{\Delta} \%$ & $\mathbf{2 0 0 8}$ \\
\hline Receita Bruta & 5.567 & 5,50 & 5.873 & 3,97 & 6.106 & 27,56 & 7.789 & 68,97 & 13.161 \\
\hline Receita Líquida & 4.883 & 5,37 & 5.145 & 1,26 & 5.210 & 27,31 & 6.633 & 71,76 & 11.393 \\
\hline Lucro Bruto & 1.351 & 7,99 & 1.459 & $-7,88$ & 1.344 & 39,36 & 1.873 & 47,30 & 2.759 \\
\hline Margem Bruta (\%) & 27,7 & 2,49 & 28,4 & $-9,03$ & 25,8 & 9,46 & 28,2 & $-14,24$ & 24,2 \\
\hline Lucro Líquido & 296 & 21,96 & 361 & $-67,59$ & 117 & 174,36 & 321 & $-51,71$ & 155 \\
\hline Margem Líquida (\%) & 6,1 & 15,75 & 7,0 & $-67,99$ & 2,2 & 115,50 & 4,8 & $-71,89$ & 1,4 \\
\hline
\end{tabular}

Fonte: Elaborada pelo autor (2021)

\subsubsection{Análise Comparativa Sadia-Perdigão}

Os próximos capítulos abordarão uma comparação entre os resultados financeiros obtidos pelas duas empresas no intervalo de 2004 a 2008 de modo segmentado.

\subsubsection{Receita Bruta}

O primeiro indicador a ser analisado é a receita bruta auferida pela Sadia e Perdigão entre 2004 e 2008. Consoante a Tabela 5 e a Figura 1, observa-se que 2006 foi o ano de menor crescimento proporcional para a Perdigão, enquanto para a Sadia foi o único período no qual a receita diminuiu em relação ao ano anterior. Após 2006, contudo, o crescimento da receita de ambas as empresas foi imponente e 2008 foi o único ano no qual a Perdigão apresentou um resultado superior à concorrente.

Tabela 5: Receita Bruta Sadia-Perdigão (2004-2008)

\begin{tabular}{|l|c|c|c|c|c|c|c|c|c|}
\hline \multicolumn{10}{|c|}{ Receita Bruta (R milhões) } \\
\hline & 2004 & $\Delta \%$ & 2005 & $\Delta \%$ & 2006 & $\Delta \%$ & 2007 & $\Delta \%$ & 2008 \\
\hline Sadia & 7.317 & 13,82 & 8.328 & $-4,66$ & 7.940 & 23,98 & 9.844 & 23,85 & 12.192 \\
\hline Perdigão & 5.567 & 5,50 & 5.873 & 3,97 & 6.106 & 27,56 & 7.789 & 68,97 & 13.161 \\
\hline
\end{tabular}

Fonte: Elaborada pelo autor (2021) 
Figura 1: Receita Bruta Sadia-Perdigão (2004-2008)

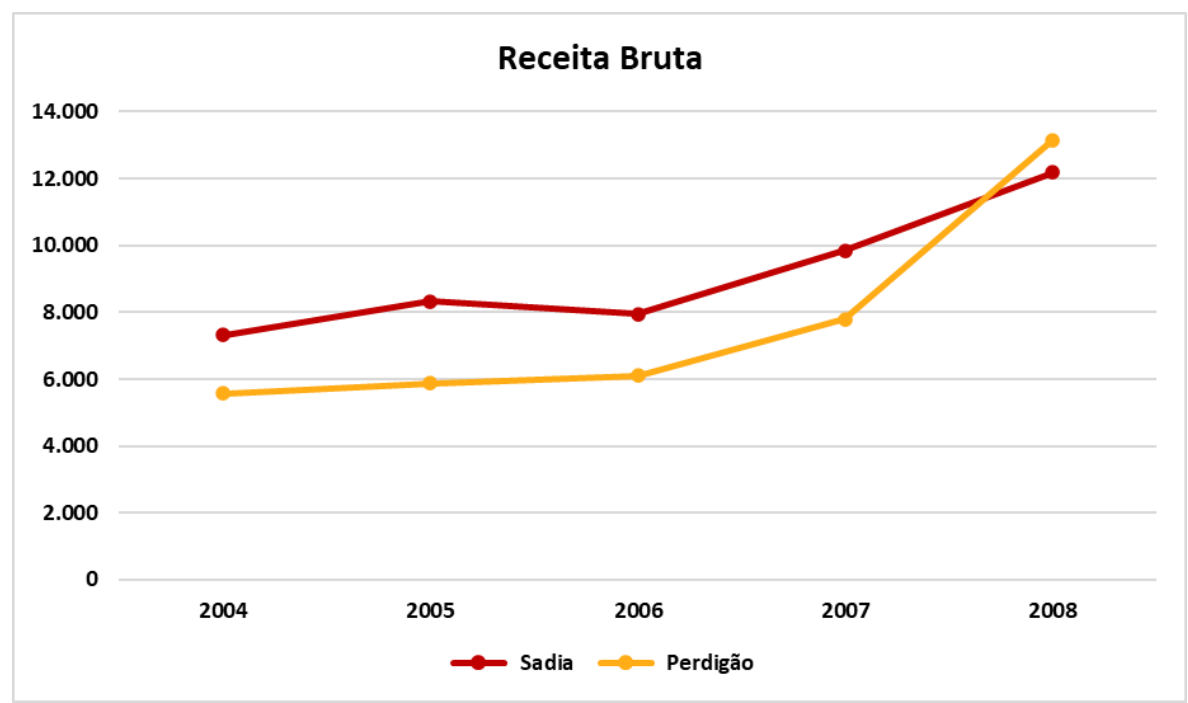

Fonte: Elaborada pelo autor (2021)

\subsubsection{Receita Líquida}

A seguir, serão apresentados dados referentes à receita líquida das companhias. Na Tabela 6 e na Figura 2, é possível constatar que a evolução dos valores ocorreu de forma semelhante à receita bruta. De modo similar à análise anterior, a receita líquida da Sadia apresentou uma redução no ano de 2006, enquanto o indicador da Perdigão evidenciou uma progressão lateral, com uma elevação de pouco mais de 1\%, menos significativa que a do intervalo anterior, quando apresentou uma ascensão superior a 5\%. Em 2008 os valores da Sadia, pela primeira vez, foram superados pelos da Perdigão.

Tabela 6: Receita Líquida Sadia-Perdigão (2004-2008)

\begin{tabular}{|l|c|c|c|c|c|c|c|c|c|}
\hline \multicolumn{10}{|c|}{ Receita Líquida (R\$ milhões) } \\
\hline & 2004 & $\Delta \%$ & 2005 & $\Delta \%$ & 2006 & $\Delta \%$ & 2007 & $\Delta \%$ & 2008 \\
\hline Sadia & 6.379 & 14,72 & 7.318 & $-6,03$ & 6.877 & 25,52 & 8.632 & 24,29 & 10.729 \\
\hline Perdigão & 4.883 & 5,37 & 5.145 & 1,26 & 5.210 & 27,31 & 6.633 & 71,76 & 11.393 \\
\hline
\end{tabular}

Fonte: Elaborada pelo autor (2021) 
Figura 2: Receita Líquida Sadia-Perdigão (2004-2008)

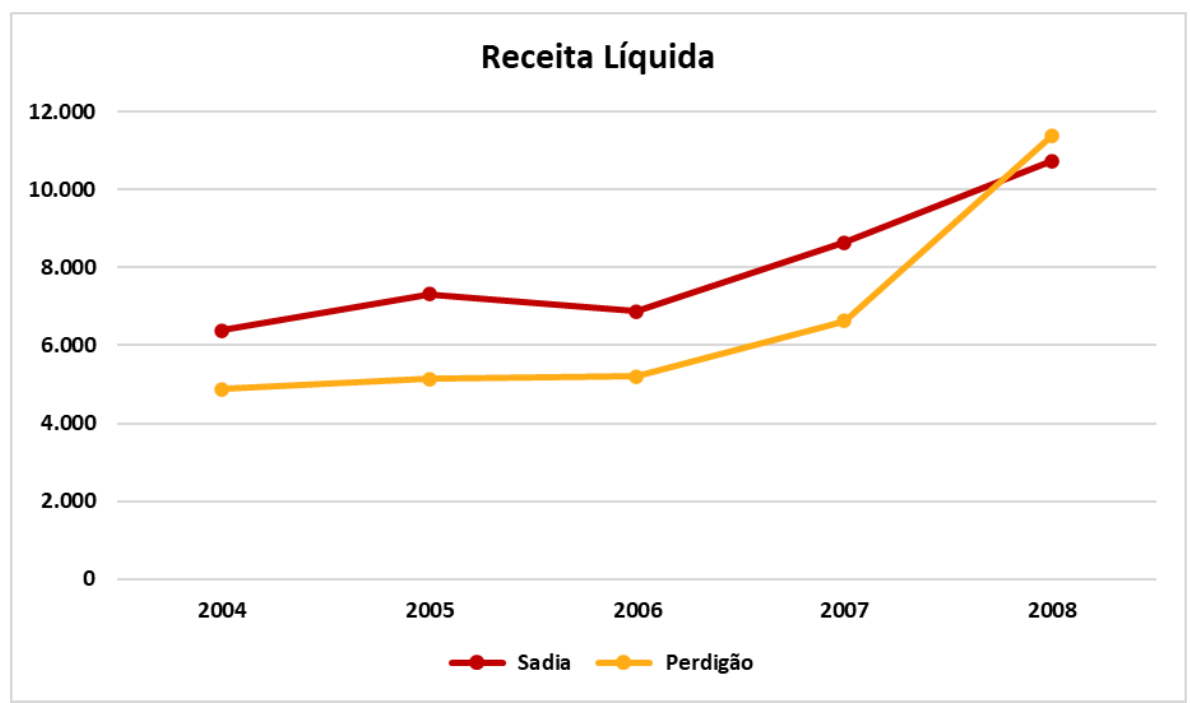

Fonte: Elaborada pelo autor (2021)

\subsubsection{Lucro Bruto}

O próximo parâmetro a ser ponderado é o lucro bruto obtido pelas companhias do setor alimentício. Diferentemente dos indicadores previamente analisados, o lucro bruto, em 2006, tanto da Sadia quanto da Perdigão apresentou uma redução. Enquanto a queda do indicador da Perdigão foi de $7,88 \%$, a contração na Sadia teve uma proporção duas vezes superior, demonstrando uma diminuição proporcional de $15,74 \%$ em relação ao resultado do ano anterior (vide Tabela 7). A partir de 2006, contudo, o lucro bruto apresentou o mesmo resultado dos demais indicadores, evidenciando uma elevação nos valores das duas companhias, com a Perdigão ultrapassando 0 resultado da Sadia em 2008, conforme a Figura 3.

Tabela 7: Lucro Bruto Sadia-Perdigão (2004-2008)

\begin{tabular}{|l|c|c|c|c|c|c|c|c|c|}
\hline \multicolumn{10}{|c|}{ Lucro Bruto (R\$ milhões) } \\
\hline & 2004 & $\Delta \%$ & 2005 & $\Delta \%$ & 2006 & $\Delta \%$ & 2007 & $\Delta \%$ & 2008 \\
\hline Sadia & 1.917 & 4,69 & 2.007 & $-15,74$ & 1.691 & 36,66 & 2.311 & 13,33 & 2.619 \\
\hline Perdigão & 1.351 & 7,99 & 1.459 & $-7,88$ & 1.344 & 39,36 & 1.873 & 47,30 & 2.759 \\
\hline
\end{tabular}

Fonte: Elaborada pelo autor (2021) 
Figura 3: Lucro Bruto Sadia-Perdigão (2004-2008)

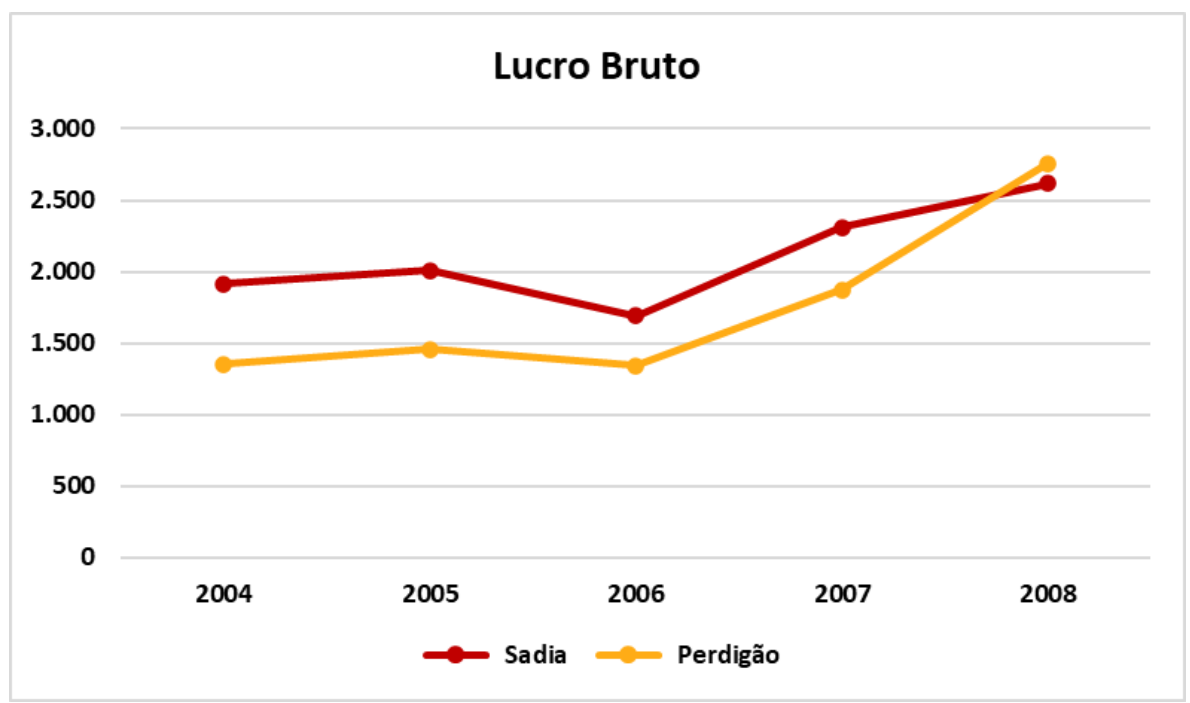

Fonte: Elaborada pelo autor (2021)

\subsubsection{Margem Bruta}

O quarto critério avaliado é a margem bruta que as empresas obtiveram nos períodos contábeis eleitos. Apenas em 2007 a Sadia apresentou crescimento na margem, sofrendo reduções nos demais anos. A Perdigão, por sua vez, também experienciou contrações de sua margem bruta nos exercícios de 2006 e 2008, recuperando-se levemente em 2007. Ao final de 2008, todavia, as margens brutas de Sadia e Perdigão se manifestaram próximas e, em oposição aos diagnósticos prévios, a Sadia apresentou o melhor resultado ao final do período, 24,4\% em oposição à margem de $24,2 \%$ exprimida pela concorrente.

Tabela 8: Margem Bruta Sadia-Perdigão (2004-2008)

\begin{tabular}{|l|c|c|c|c|c|c|c|c|c|}
\hline \multicolumn{10}{|c|}{ Margem Bruta (\%) } \\
\hline & 2004 & $\Delta \%$ & 2005 & $\Delta \%$ & 2006 & $\Delta \%$ & 2007 & $\Delta \%$ & 2008 \\
\hline Sadia & 30,1 & $-8,97$ & 27,4 & $-10,22$ & 24,6 & 8,94 & 26,8 & $-8,96$ & 24,4 \\
\hline Perdigão & 27,7 & 2,53 & 28,4 & $-9,15$ & 25,8 & 9,30 & 28,2 & $-14,18$ & 24,2 \\
\hline
\end{tabular}

Fonte: Elaborada pelo autor (2021) 
Figura 4: Margem Bruta Sadia-Perdigão (2004-2008)

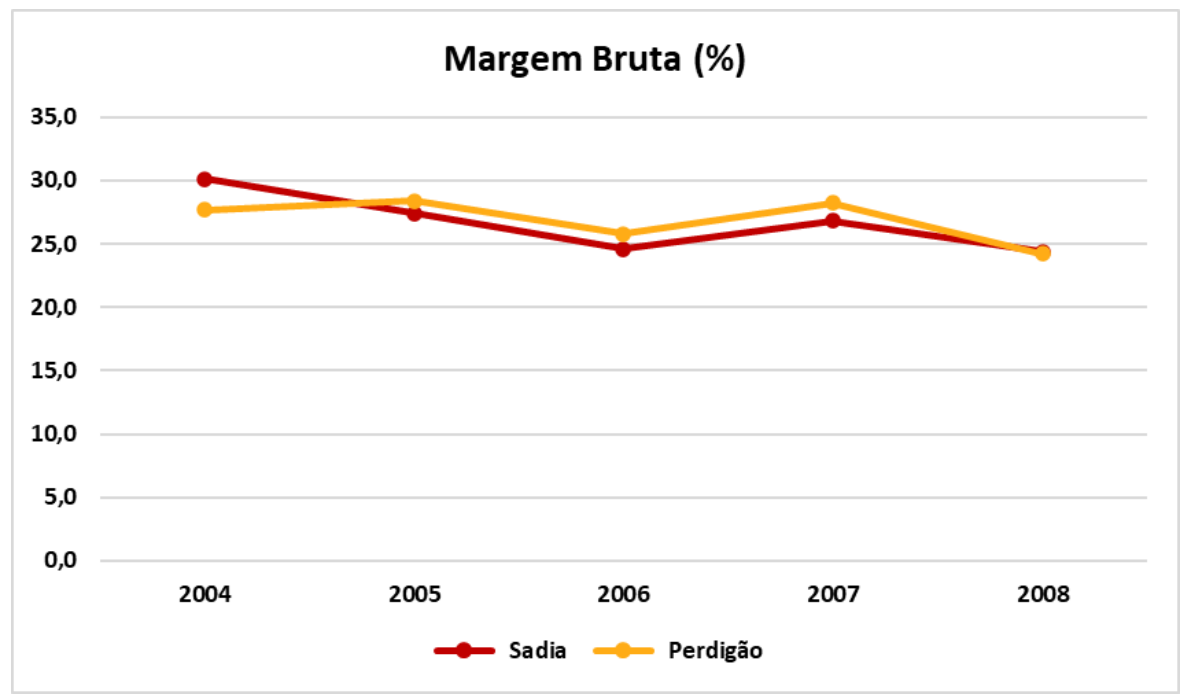

Fonte: Elaborada pelo autor (2021)

\subsubsection{Lucro Líquido}

A respeito do lucro líquido, é possível constatar uma maior divergência nos valores apurados. No ano de 2006, o lucro líquido de ambas as empresas apresentou uma redução expressiva. Ao passo que o lucro líquido da Sadia foi impactado em mais de $40 \%$, a Perdigão sofreu um baque superior a $67 \%$, reduzindo seu lucro líquido para um terço do auferido no exercício anterior (vide Tabela 9). No entanto, em 2008, ainda que a Perdigão tenha vivenciado uma nova queda de $50 \%$, a Sadia enfrentou uma contração de $460 \%$, incorrendo em um prejuízo líquido de $R \$ 2,5$ bilhões, devido ao fracasso nas operações financeiras realizadas, conforme já mencionado anteriormente.

Tabela 9: Lucro Líquido Sadia-Perdigão (2004-2008)

\begin{tabular}{|l|c|c|c|c|c|c|c|c|c|}
\hline \multicolumn{10}{|c|}{ Lucro Líquido (R\$ milhões) } \\
\hline & 2004 & $\Delta \%$ & 2005 & $\Delta \%$ & 2006 & $\Delta \%$ & 2007 & $\Delta \%$ & 2008 \\
\hline Sadia & 439 & 49,66 & 657 & $-42,62$ & 377 & 82,76 & 689 & $-460,67$ & -2.485 \\
\hline Perdigão & 296 & 21,96 & 361 & $-67,59$ & 117 & 174,36 & 321 & $-51,71$ & 155 \\
\hline
\end{tabular}

Fonte: Elaborada pelo autor (2021) 
Figura 5: Lucro Líquido Sadia-Perdigão (2004-2008)

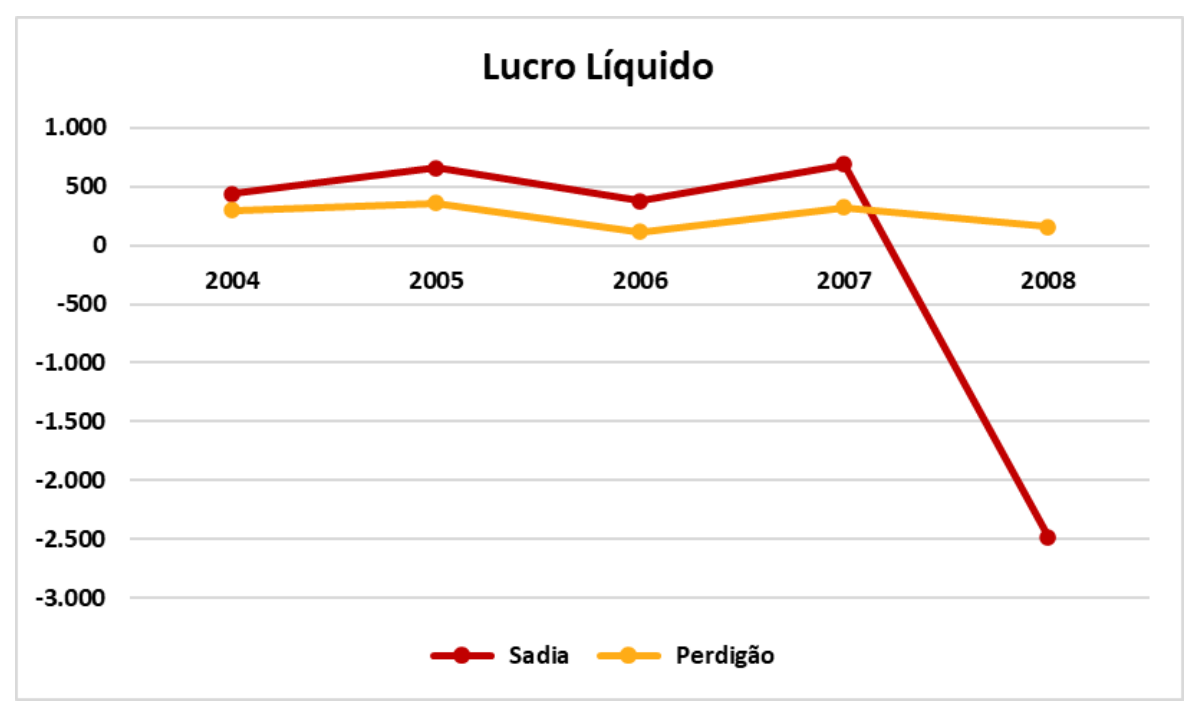

Fonte: Elaborado pelo autor (2021)

\subsubsection{Margem Líquida}

Em conformidade com os resultados coletados a respeito do lucro líquido, a margem líquida das empresas seguiu a mesma trajetória. Tanto Sadia como Perdigão passaram por uma retração considerável em 2006, recuperando-se levemente no exercício consecutivo, em 2007. Já em 2008, enquanto a Perdigão sofreu uma nova queda, a margem líquida da Sadia despencou 390\%, alcançando o patamar de $-23,2 \%$ em relação à receita líquida.

Tabela 10: Margem Líquida Sadia- Perdigão (2004-2008)

\begin{tabular}{|l|c|c|c|c|c|c|c|c|c|}
\hline \multicolumn{10}{|c|}{ Margem Líquida (\%) } \\
\hline & 2004 & $\Delta \%$ & 2005 & $\Delta \%$ & 2006 & $\Delta \%$ & 2007 & $\Delta \%$ & 2008 \\
\hline Sadia & 6,9 & 30,43 & 9,0 & $-38,89$ & 5,5 & 45,45 & 8,0 & $-390,00$ & $-23,2$ \\
\hline Perdigão & 6,1 & 14,75 & 7,0 & $-68,57$ & 2,2 & 118,18 & 4,8 & $-70,83$ & 1,4 \\
\hline
\end{tabular}

Fonte: Elaborado pelo autor (2021) 
Figura 6: Margem Líquida Sadia-Perdigão (2004-2008)

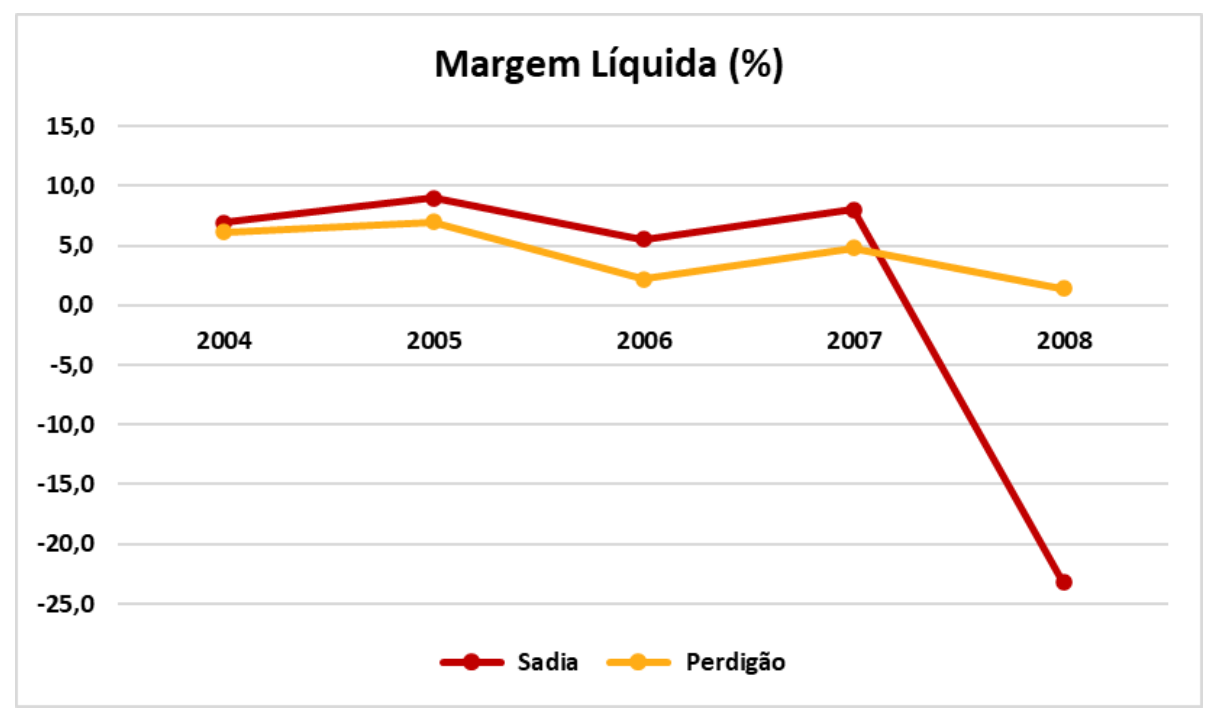

Fonte: Elaborado pelo autor (2021)

\subsection{Impacto na Cotação das Ações}

Nas seções seguintes, será demonstrado o impacto causado na cotação das ações pelo caso de insider trading. Em um primeiro momento, será apresentada a reação do mercado frente à divulgação da Oferta Pública de Aquisição da Sadia e, dias depois, diante da recusa da oferta pela Perdigão. O presente trabalho relatará ainda o comportamento das ações em consequência das condenações dos executivos da Sadia.

\subsubsection{Perdigão}

À época do episódio, na Bolsa de Valores brasileira, as ações da Perdigão S.A. eram negociadas sob o ticker PRGA3. Contudo, após a incorporação da Sadia pela Perdigão, em 2009, se originou a BRF - Brasil Foods S.A. e os títulos passaram a ser negociados sob um novo código, BRFS3. Na New York Stock Exchange ("NYSE"), por sua vez, os papéis, que eram negociados sob o código PDA, foram convertidos para o ticker BRFS.

A seguir, será apresentado o gráfico de cotações do ADR da Perdigão, negociado na Bolsa de Nova York. Primordialmente, a primeira seta destaca o momento de comunicação ao mercado da Oferta Pública de Ações (OPA), em 16 de julho de 2006. No dia 14 de julho, uma sexta-feira, a cotação de fechamento do ADR foi de US\$5,06 e, na abertura do mercado em 17 de julho, segunda-feira, dia seguinte ao anúncio, o papel estava sendo negociado a US\$ 
5,78, apresentando máxima intradiária de US\$ 6,19 e, ao fechamento do dia, o título estava cotado em US\$ 6,12.

Consoante o gráfico a seguir, nos dias subsequentes, o ADR evidenciou uma alta de mais de $35 \%$ em relação ao fechamento do pregão anterior à comunicação da OPA por parte da Sadia, alcançando a cotação máxima de US\$ 6,84 . Contudo, a segunda seta está relacionada ao pregão de 21 de julho de 2006, data da revogação da oferta pela Sadia, ocasionando uma queda superior a US\$1,00 em relação à máxima, levando a ação a ser negociada, em sua mínima diária, a US\$5,69.

Figura 7: Cotação NYSE: PDA (junho/2006 a agosto/2006)

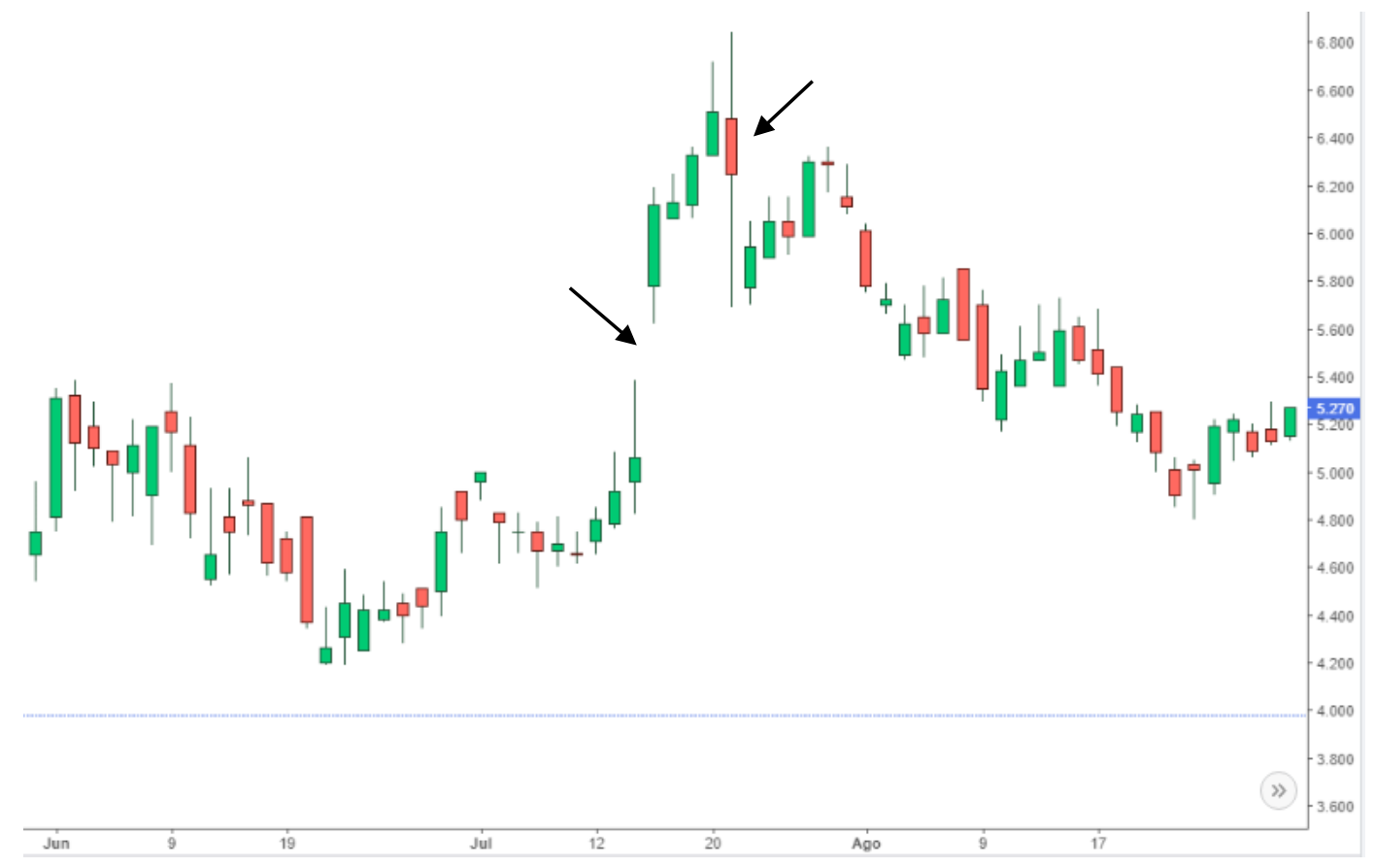

Fonte: br.investing.com

O próximo gráfico a ser apresentado é referente à cotação das ações da Perdigão (PRGA3) no mercado acionário brasileiro. Assim como indicado na imagem anterior, nos momentos de divulgação da oferta por parte da Sadia e recusa da mesma pela Perdigão, a ação sofreu um impacto significativo, destacado também na Figura 8, mais adiante, através de setas. Previamente à divulgação da OPA, no dia 14 de julho de 2006, ao fechamento do pregão, os papéis eram cotados a $R \$ 10,34$. Na segunda-feira, dia 17 de julho, pregão imediatamente posterior à alegada comunicação aos investidores a respeito da OPA, o mercado já precificava a ação a $R \$ 11,91$, alcançando sua cotação máxima intradiária de $\mathrm{R} \$ 12,31$. 
Assim como evidenciado no gráfico referente à cotação dos ADRs, nos dias consecutivos, o título chegou a atingir o valor culminante de $R \$ 13,28$, apresentando uma elevação de aproximadamente $28,5 \%$ relativamente à última cotação do dia 14. No dia 21 de julho de 2006, data da publicação da negação à oferta pela Perdigão, a ação sofreu uma forte queda, atingindo um patamar mínimo de $R \$ 11,26$, devalorização superior a $R \$ 2,00$.

Figura 8: Cotação PRGA3 (junho/2006 a agosto/2006)

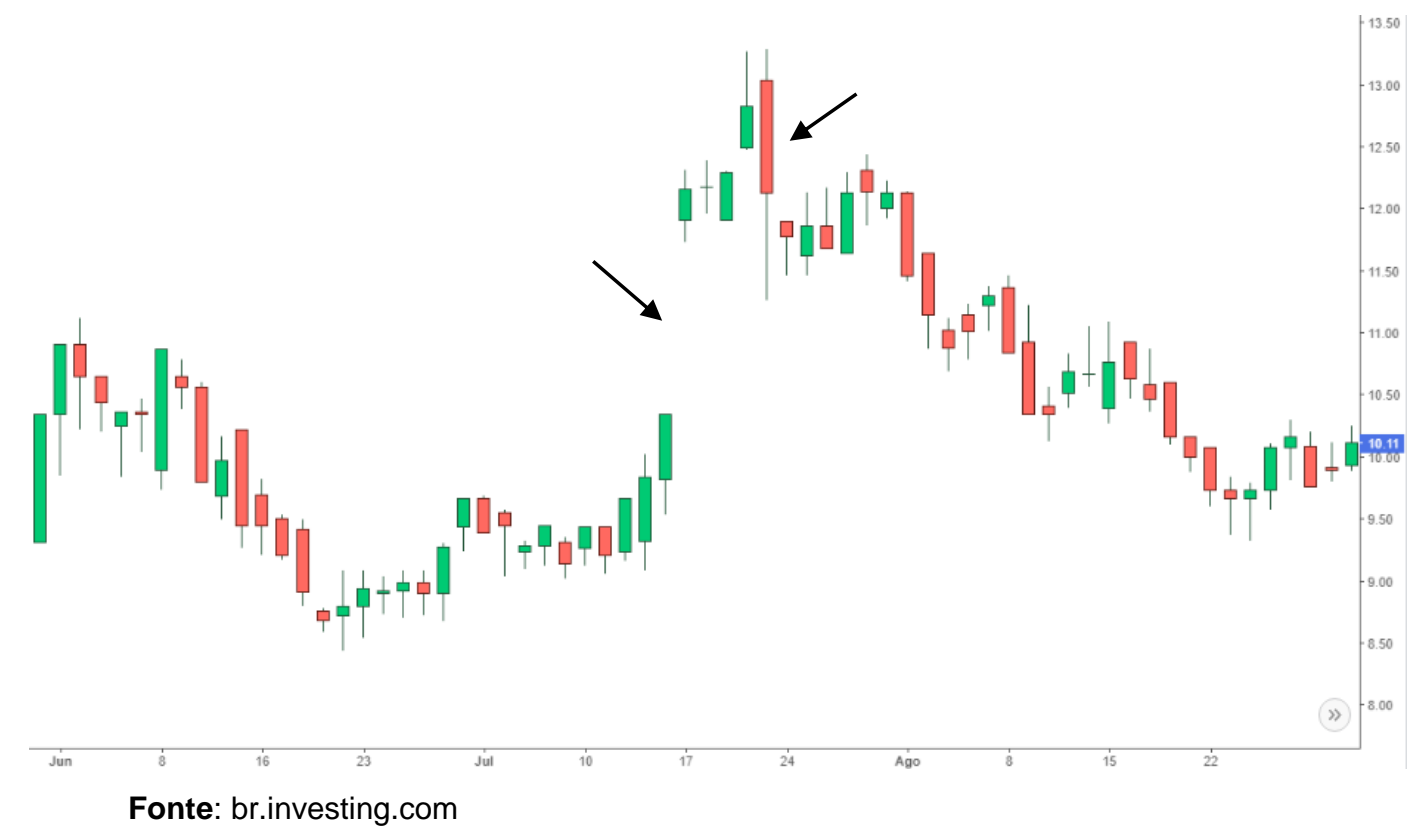

A seguir será exibido o impacto nos ADRs da Perdigão, negociados na Bolsa de Nova York, perante a divulgação da punição dos insiders pela Securities and Exchange Commission (SEC). Em 22 de fevereiro de 2007, a SEC anunciou as penas impostas aos envolvidos no caso, que abrangiam multas e o afastamento de cargos administrativos de quaisquer empresas listadas em bolsas nos Estados Unidos.

Conforme o gráfico de cotação dos ADRs à época da comunicação da SEC (Figura 9), os recibos, que no dia 22 eram negociados na faixa dos US\$ 6,50 , desvalorizaram-se, alcançando US\$ 5,73 e, em poucos dias, aproximaramse dos US\$ 5,60. No entanto, é possível analisar que, em menos de um mês, os títulos já haviam se recuperado e, ao final de abril, já estavam sendo cotados a US\$7,58. 
Figura 9: Cotação NYSE: PDA (fevereiro/2007 a abril/2007)

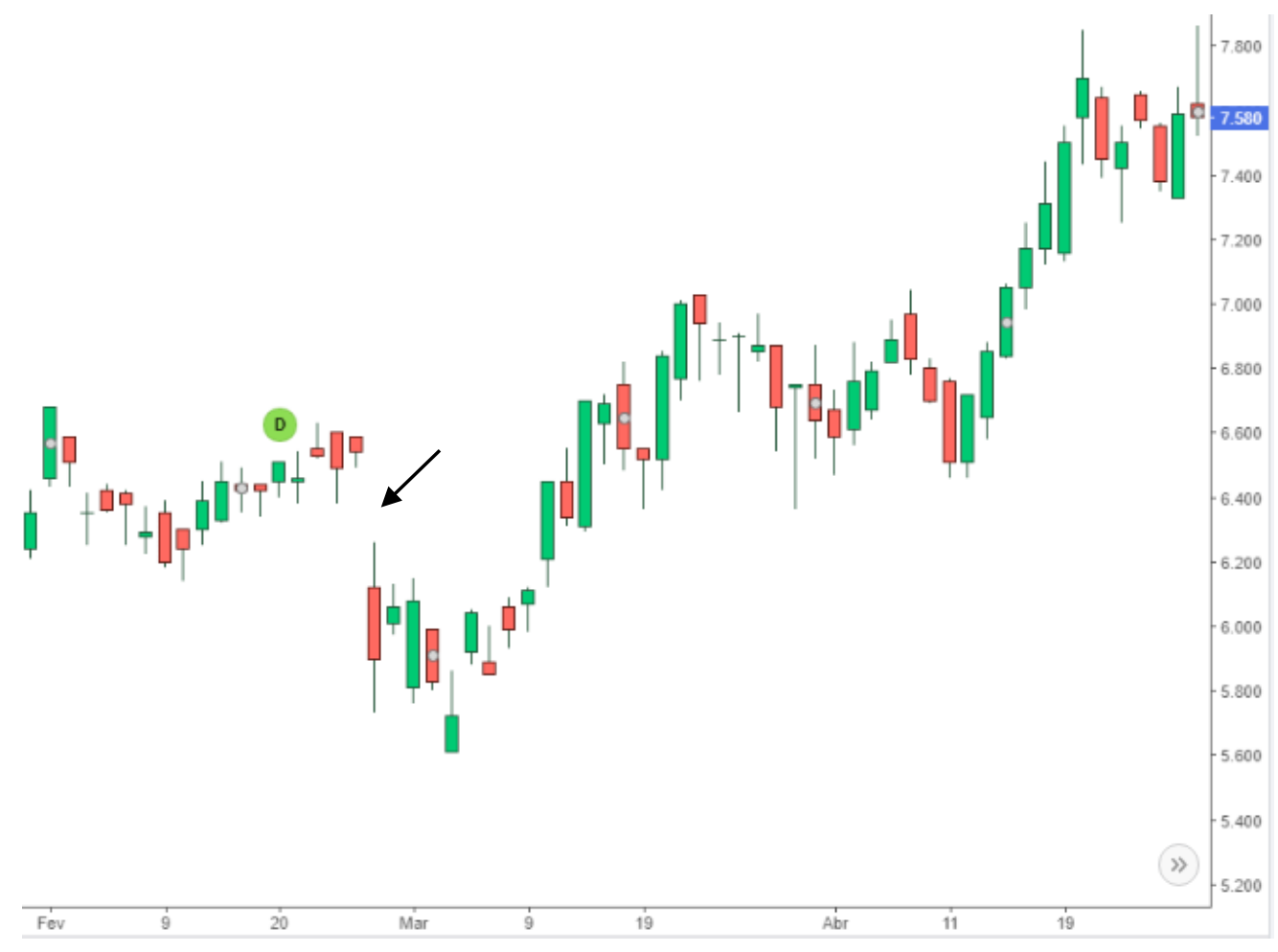

Fonte: br.investing.com

O mesmo efeito ocorreu com as ações da Perdigão negociadas na bolsa brasileira (vide Figura 10). Previamente ao anúncio da punição por parte da SEC, o valor de negociação dos títulos se encontrava no intervalo de $R \$ 12,10$ e $\mathrm{R} \$ 12,30$ e, no momento que a condenação se tornou pública, os títulos caíram ao preço de $R \$ 11,06$, atingindo uma mínima, em questão de dias, de $R \$ 10,65$. Assim como averiguado na Figura 9, as ações não permaneceram em queda, mas se recuperaram e fecharam o mês de abril em alta relevante, cotadas a $R \$$ 13,73 . 
Figura 10: Cotação PRGA3 (fevereiro/2007 a abril/2007)

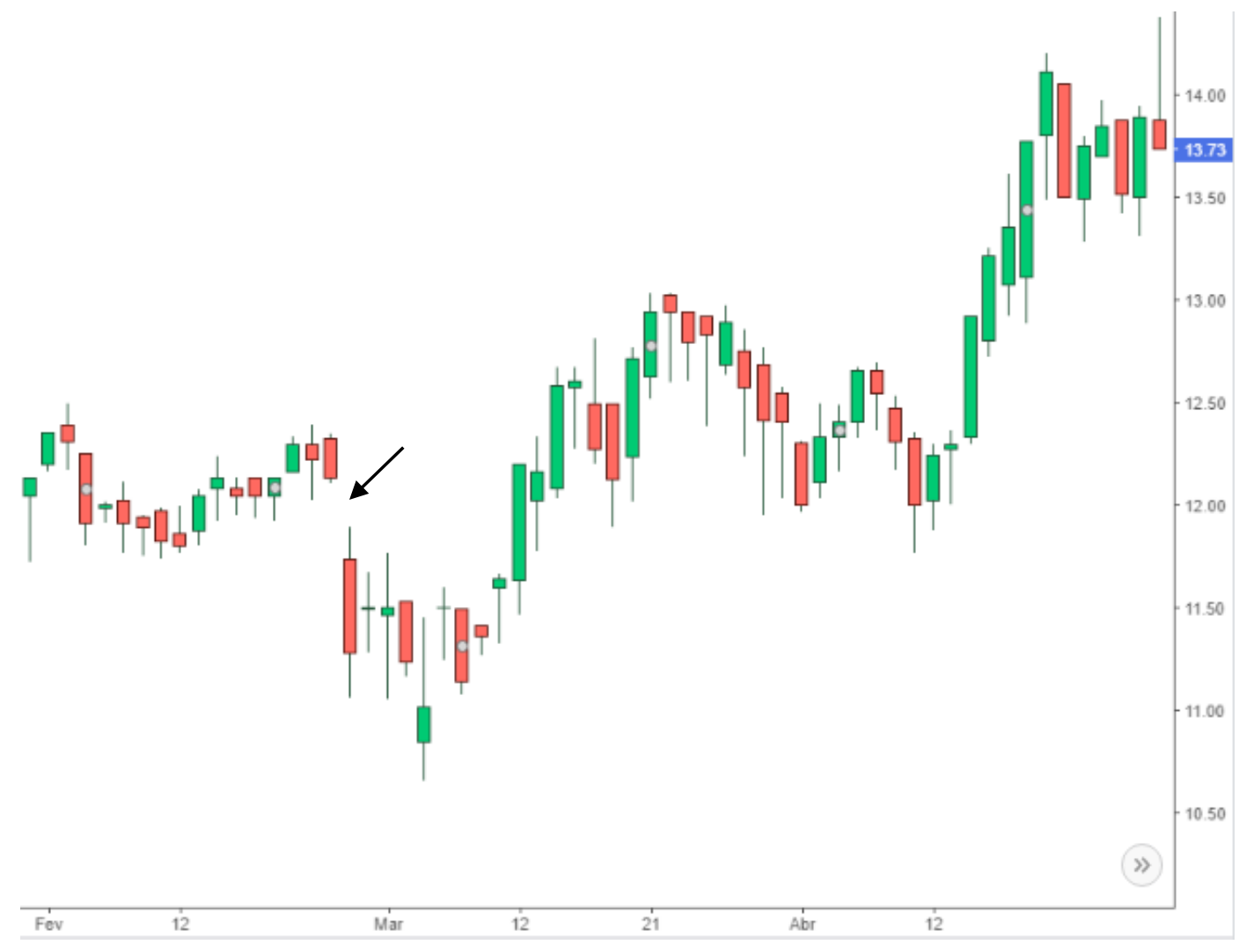

Fonte: br.investing.com

\subsubsection{Sadia}

As ações do Grupo Sadia foram negociadas até o pregão de 21 de novembro de 2009, devido à incorporação pela concorrente Perdigão, a partir da qual foram convertidas em ações da Brasil Foods (BRFS3), originárias a partir da operação.

A divulgação da Oferta Pública de Aquisição (OPA) foi feita, como já mencionado, no dia 16 de julho de 2006, domingo. Conforme os destaques no gráfico abaixo (Figura 11), na sexta-feira, 14 de julho, as ações da Sadia, ao fechamento do pregão, estavam cotadas a $R \$ 5,61$. Após a comunicação feita ao mercado, na segunda-feira, dia 17 de julho, as ações alcançaram o valor máximo de $R \$ 6,10$, reagindo positivamente ao anúncio. No dia 21 de julho, no entanto (vide segunda ênfase na figura), frente à rejeição da Perdigão, as ações caíram ao patamar de $\mathrm{R} \$ 5,90$. 
Figura 11: Cotação SDIA4 (junho/2006 a agosto/2006)

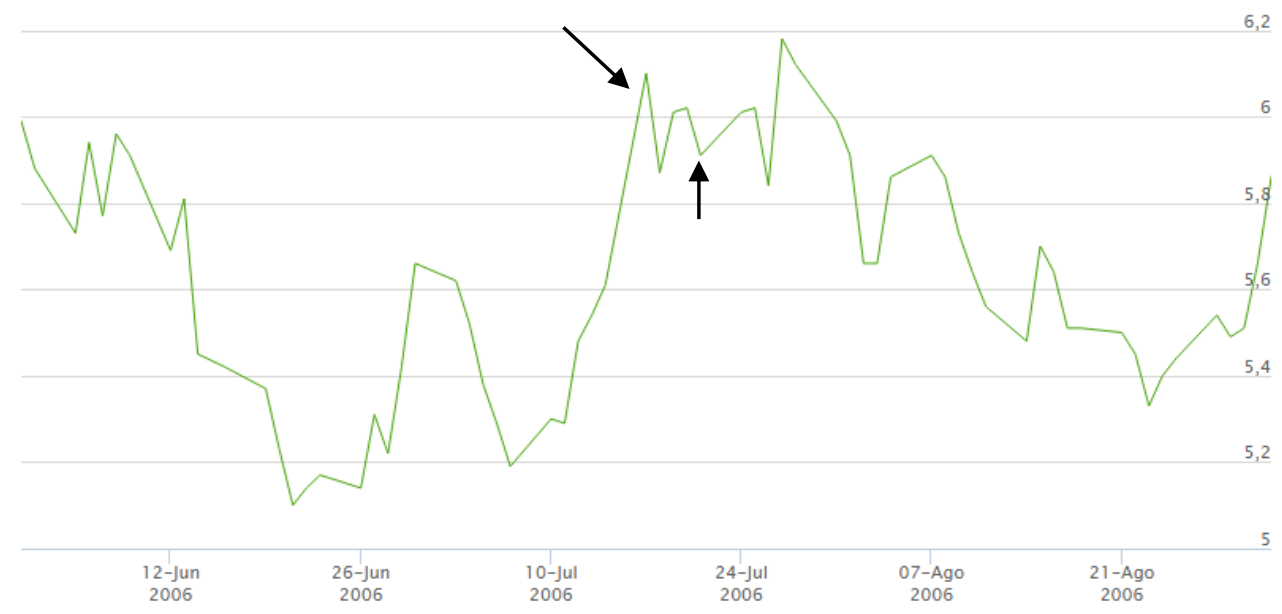

Fonte: fundamentus.com

O gráfico a seguir (Figura 12) faz referência ao impacto causado pela condenação da SEC aos executivos envolvidos no episódio de insider trading na cotação das ações da Sadia. Anteriormente à divulgação da SEC sobre a condenação dos acusados, os títulos estavam sendo negociados a uma cotação de $R \$ 7,15$, evidenciando, após a comunicação da decisão jurídica, uma queda próxima de $10,5 \%$, recuando até a faixa de $R \$ 6,40$. Do mesmo modo que comprovado pela análise do comportamento das ações da Perdigão, o valor das ações não apenas se recuperou rapidamente, mas se elevou significativamente perante o valor anterior à divulgação do fato e, ao final do mês de abril de 2007 , já era de $\mathrm{R} \$ 8,80$.

Figura 12: Cotação SDIA4 (fevereiro/2007 a abril/2007)

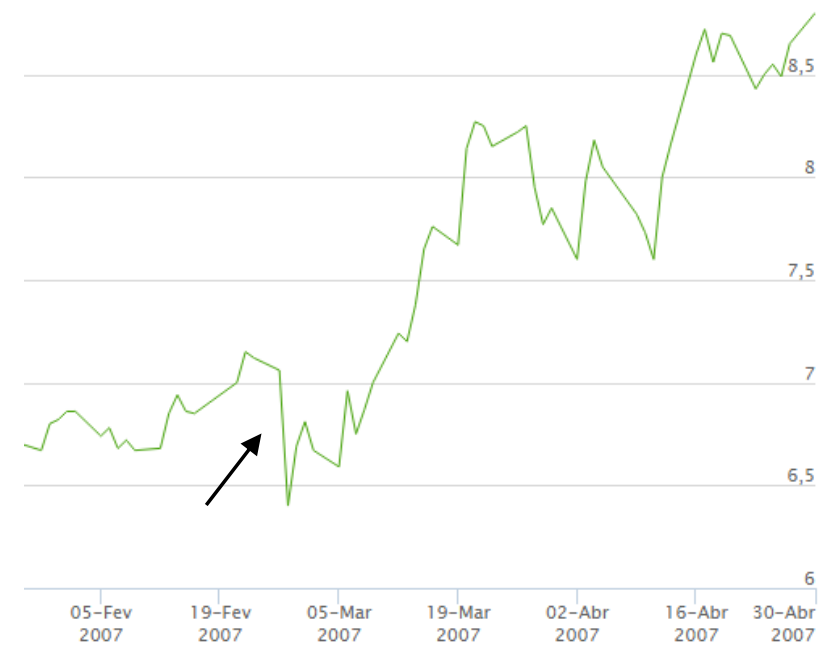

Fonte: fundamentus.com 


\section{Conclusão}

A principal finalidade do presente trabalho foi avaliar os impactos causados pelo caso de insider trading Sadia-Perdigão, a partir da análise dos resultados financeiros auferidos pelas empresas e da performance de seus respectivos valores mobiliários, negociados na B3, a Bolsa de Valores do Brasil (à época do episódio BM\&FBOVESPA), e na New York Stock Exchange (NYSE), através de um American Depositary Receipt (ADR).

Com o objetivo de averiguar os impactos, foram apurados os resultados financeiros das companhias entre os anos de 2004 e 2008, viabilizando um diagnóstico dos exercícios anteriores e posteriores ao episódio. A respeito do comportamento das ações, foram analisadas as reações dos investidores em dois momentos: i) no intervalo dos dias 16 e 21 de julho de 2021, respectivamente referentes à comunicação da Oferta Pública de Aquisição por parte da Sadia e à rejeição desta pelos acionistas da Perdigão; e ii) 22 de fevereiro de 2007, momento de divulgação da condenação dos envolvidos em nome da SEC.

Em conformidade com as informações coletadas e analisadas no capítulo anterior, evidencia-se, de fato, um impacto, sob ambas as óticas, nas duas empresas. No que concerne aos resultados financeiros anuais, constata-se que, em 2006, exercício marcado pela ocorrência do caso de insider trading, tanto Sadia como Perdigão sofreram impacto. As duas instituições, no tocante aos seus lucros, bruto e líquido, em relação ao ano anterior (2005), conferiram uma redução nos valores obtidos.

A respeito das receitas, bruta e líquida, enquanto a Sadia, do mesmo modo, sofreu uma contração, ainda que menos acentuada, Perdigão conquistou uma ampliação nos números, sendo esta, no entanto, proporcionalmente a menor dentre as analisadas nos demais períodos. Apesar disso, em 2007, as duas companhias manifestaram recuperação frente ao exercício prévio.

Já em 2008, como demonstrado, a Perdigão, apesar da crise financeira global, auferiu uma elevação média de $70 \%$ em sua receita (bruta e líquida). No que tange ao lucro bruto e líquido, ainda que significativamente inferiores aos de 2007, apresentaram resultado positivo, não incorrendo em prejuízo. Por sua vez, 
a Sadia, em 2008, como já exposto, declarou um prejuízo bilionário, resultado de sua alavancagem financeira a partir de operações de hedge contra a desvalorização do dólar, por conseguinte, sem qualquer relação com o episódio de insider trading.

O caso Sadia-Perdigão repercutiu ainda na cotação das ações das duas empresas e, por ter envolvido a negociação de ADRs na Bolsa de Valores de Nova York, refletiu no valor destes. Consoante os dados examinados, no pregão seguinte ao dia em que a Sadia divulgou a Oferta Pública de Aquisição aos investidores, em 17 de julho de 2006, foi constatada uma elevação expressiva no preço dos 3 títulos (PDA, PRGA3 e SDIA4). No dia 21 de julho, contudo, após a negação pública por parte da Perdigão, detectou-se uma brusca queda nos papéis, mais relevante e prolongada nos títulos da própria Perdigão.

A segunda ocasião na qual foi observado o comportamento dos investidores, instabilizando o valor dos ativos, corresponde à condenação dos insiders por parte da Securities and Exchange Commission (SEC). Em fevereiro de 2007, após a comunicação a respeito da punição determinada aos executivos pelo órgão regulador norte-americano, o mercado reagiu e, novamente, desvalorizou os títulos de Sadia e Perdigão. Entretanto, nesta circunstância, as ações rapidamente se recuperaram e, inclusive, superaram a faixa de preço antecedente à divulgação da sentença definida. Ao final de abril, isto é, em menos de um mês e meio após o impacto sofrido pela condenação dos insiders, os três valores mobiliários já evidenciavam o maior patamar de preços, até então, desde o início de 2007.

Assim sendo, é possível inferir que, ainda que um caso de insider trading, inquestionavelmente, afete a(s) empresa(s) envolvida(s), tais impactos não se comprovam definitivos, sendo exequível superá-los e reassumir a trajetória crescente, tal como corroborado pela evolução da Perdigão. 


\section{Referências Bibliográficas}

BOLSON, A. L.; KRIEGER, J. R. Crime de insider trading e a aplicabilidade do direito penal máximo. In: SOUZA, J. A. et al. Inovação em Segurança Pública. Santa Catarina: FUCAP, 2018.

BRASIL. Lei no 6.385, de 7 de dezembro de 1976. Disponível em: <http://www.planalto.gov.br/ccivil_03/leis/L6385.htm>. Acesso em: 13 out. 2021.

Consultor Jurídico. Ex-diretor da Sadia é o primeiro condenado no Brasil por insider trading. 22 fev. 2016. Disponível em: <https://www.conjur.com.br/2016fev-22/stj-profere-primeira-condenacao-insider-trading-brasil>. Acesso em: 10 set. 2021.

Custódio \& Goes. O que é Insider Trading? São Paulo, 2 ago. 2018. Disponível em: <https://custodiogoes.jusbrasil.com.br/artigos/607657721/o-que-e-insidertrading >. Acesso em: 20 abr. 2021.

CVM. Instrução CVM no 358. Rio de Janeiro, 3 jan. 2002. Disponível em: <http://conteudo.cvm.gov.br/legislacao/instrucoes/inst358.html>. Acesso em: 13 out. 2021.

Folha de São Paulo. Perdas com derivativos desencadearam acordo. São Paulo, 19 maio $2009 . \quad$ Disponível em <https://www1.folha.uol.com.br/fsp/dinheiro/fi1905200907.htm>. Acesso em: 25 set. 2021.

Forbes. The High Crimes And Misadventures Of William Duer, The Founding Father Who Swindled America. 04 jul. 2019. Disponível em: https://www.forbes.com/sites/abrambrown/2019/07/04/the-high-crimes-andmisadventures-of-william-duer-the-founding-father-who-swindledamerica/?sh=54b010ab79dc. Acesso em: 30 set. 2021. 
Fundamentus. Balanços em Excel Sadia. Disponível em <http://www.fundamentus.com.br/balancos.php?papel=sdia4\&tipo=1>. Acesso em: 15 out. 2021.

Fundamentus. Histórico de Cotações BRFS3. Disponível em: <http://www.fundamentus.com.br/cotacoes.php?papel=BRFS3>. Acesso em: 27 out. 2021.

Fundamentus. Histórico de Cotações SDIA4. Disponível em: <http://www.fundamentus.com.br/cotacoes.php?papel=sdia4>. Acesso em: 27 out. 2021.

GRAZIANI, A. R. A Ineficiência da Criminalização do Insider Trading no Brasil. Brasília, 2018. Dissertação (Bacharelado em Direito) - Faculdade de Ciências Jurídicas e Sociais (FAJS): Centro Universitário de Brasília - Uniceub.

HAIDAR, D. Justiça eleva punição contra ex-executivos da Sadia por 'insider trading'. O Globo, Rio de Janeiro, 04 fev. 2013. Disponível em: $<$ https://oglobo.globo.com/economia/justica-eleva-punicao-contra-ex-executivosda-sadia-por-insider-trading-7492987>. Acesso em: 23 set. 2021.

Investing.com. Gráfico BRF SA (BRFS3). Disponível em: $<$ https://br.investing.com/equities/brf-foods-on-ej-nm-chart>. Acesso em: 27 out. 2021.

Investing.com. Gráfico BRF SA ADR (BRFS). Disponível em: $<$ https://br.investing.com/equities/brf-brasil-foods-sa-chart>. Acesso em: 27 out. 2021.

LOYD, P. The Man Behind The Panic Of 1972 And The First Wall Street Insider. Forbes, $2017 . \quad$ Disponível em: $<$ https://www.forbes.com/sites/realspin/2017/04/05/the-man-behind-the-panic-of1792-and-the-first-wall-street-insider/?sh=45bb49e57a71> Acesso em: 17 abr. 2021.

MAHONEY, P. G. The Political Economy of the Securities Act of 1933. Journal of Legal Studies, Vol. 30, No. 1, 2001. 
MARTINS, T. S. Insider Trading: Análise sobre o caso Sadia-Perdigão. Jusbrasil, $2019 . \quad$ Disponível em: <https://tico080970.jusbrasil.com.br/artigos/706006035/insider-trading-analisesobre-o-caso-sadia-perdigao>. Acesso em: 28 set. 2021.

O Globo. Caso Sadia-Perdigão gera primeira condenação penal por uso de informação privilegiada. Rio de Janeiro, 18 fev. 2011. Disponível em: $<$ https://oglobo.globo.com/economia/caso-sadia-perdigao-gera-primeiracondenacao-penal-por-uso-de-informacao-privilegiada-2821605>. Acesso em: 10 set. 2021.

O Globo. SEC pune dois 'insiders' do caso Sadia-Perdigão. Rio de Janeiro, 23 fev. 2007. Disponível em: <https://oglobo.globo.com/economia/sec-pune-doisinsiders-do-caso-sadia-perdigao-4213617>. Acesso em: 10 set. 2021.

PARENTE, N. J. Aspectos Jurídicos do "insider trading". Comissão De Valores Mobiliários, Superintendência Jurídica, 1978. Disponível em: <http://conteudo.cvm.gov.br/export/sites/cvm/menu/acesso_informacao/serieshis toricas/estudos/anexos/Aspectos-Juridicos-do-insider-trading-NJP.pdf> Acesso em: 17 abr. 2021.

REIS, T. Lucro bruto: um importante indicador de lucratividade de um negócio. Suno Research, 16 fev. 2018. Disponível em: < https://www.suno.com.br/artigos/lucro-bruto/>. Acesso em: 30 nov. 2021.

REIS, T. Lucro líquido: saiba o que é e como calculá-lo. Suno Research, 14 fev. 2018. Disponível em: < https://www.suno.com.br/artigos/lucro-liquido/>. Acesso em: 30 nov. 2021.

REIS, T. Margem Bruta: entenda o que é e qual a sua importância. Suno Research, 01 nov. 2019. Disponível em: < https://www.suno.com.br/artigos/margem-bruta-entenda-sua-importancia/>. Acesso em: 30 nov. 2021. 
REIS, T. Margem liquida: entenda como analisar esse indicador de lucratividade. Suno Research, 08 dez. 2017. Disponível em: < https://www.suno.com.br/artigos/margem-liquida/>. Acesso em: 30 nov. 2021.

REIS, T. O que é receita líquida: saiba como calcular esse importante indicador. Suno Research, 23 mar. 2018. Disponível em: < https://www.suno.com.br/artigos/o-que-receita-liquida/>. Acesso em: 30 nov. 2021.

REIS, T. Receita bruta: conheça o indicador de vendas de uma empresa. Suno Research, 23 mar. 2018. Disponível em: < https://www.suno.com.br/artigos/o-que-receita-bruta/>. Acesso em: 30 nov. 2021.

SCHELLER, F.; NAIME, L. União de Sadia e Perdigão cria 'gigante' brasileira dos alimentos. G1, São Paulo, 19 maio 2009. Disponível em: <https://g1.globo.com/Noticias/Economia_Negocios/0,,MUL1125247-9356,00UNIAO+DE+SADIA+E+PERDIGAO+CRIA+GIGANTE+BRASILEIRA+DOS+ALIM ENTOS.html>. Acesso em: 14 set. 2021.

SEC. 2013 Insider Trading Policy. Disponível em: <https://www.sec.gov/Archives/edgar/data/25743/000138713113000737/ex14_0 2.htm>. Acesso em: 20 set. 2021.

SETTI, R. Condenados na CVM, crimes de informação privilegiada chegam pouco à Justiça. O Globo, Rio de Janeiro, 14 fev. 2018. Disponível em: $<$ https://oglobo.globo.com/economia/condenados-na-cvm-crimes-de-informacaoprivilegiada-chegam-pouco-justica-22394865>. Acesso em: 28 set. 2021. 